\title{
In vitro and in vivo Activity of Combinations of Polymyxin B with Other Antimicrobials Against Carbapenem-Resistant Acinetobacter baumannii [Corrigendum]
}

Zhang $\mathrm{H}$, Zhu Y, Yang $\mathrm{N}$, et al. Infect Drug Resist. 2021;14:4657-4666.

Page 4660, Table 1, Notes: section, the text "RIF, susceptible $\leq 2$, resistant $\geq 4$ (according to Working Party Report of BSAC);" should read "RIF, susceptible $\leq 2$, resistant $\geq 4$ (breakpoints based on Tan et $\mathrm{al}^{37}$ and Bai et $\left.\mathrm{al}^{38}\right) ; "$.

The authors also wish to add the following two references to the end of the reference section on page 4666 .
37. Tan TY, Ng LS, Poh K. Susceptibility testing of unconventional antibiotics against multiresistant Acinetobacter spp. by agar dilution and Vitek 2. Diagn Microbiol Infect Dis. 2007;58(3):357-361. doi:10.1016/j.diagmicrobio.2007.02.008

38. Bai Y, Liu B, Wang $\mathrm{T}$, et al. In Vitro activities of combinations of rifampin with other antimicrobials against multidrug-resistant Acinetobacter baumannii. Antimicrob Agents Chemother. 2015;59(3):1466-1471. doi:10.1128/ AAC.04089-14

The authors apologize for this error.

\section{Publish your work in this journal}

Infection and Drug Resistance is an international, peer-reviewed openaccess journal that focuses on the optimal treatment of infection (bacterial, fungal and viral) and the development and institution of preventive strategies to minimize the development and spread of resistance. The journal is specifically concerned with the epidemiology of antibiotic resistance and the mechanisms of resistance development and diffusion in both hospitals and the community. The manuscript management system is completely online and includes a very quick and fair peerreview system, which is all easy to use. Visit http://www.dovepress.com/ testimonials.php to read real quotes from published authors. 